\title{
Identifikasi Sistim Peternakan di Manokwari, Papua Barat-Indonesia
}

\section{The Identification of Livestock Farming Systems in Manokwari, West Papua-Indonesia}

\author{
D. A. Iyai ${ }^{1}$ dan A. Yaku ${ }^{2}$ \\ ${ }^{1}$ Fakultas Peternakan, Universitas Papua. Jl. Gunung Salju, Amban. Manokwari 98314 \\ ${ }^{2}$ Fakultas Pertanian, Universitas Papua. Jl. Gunung Salju, Amban. Manokwari 98314 \\ email: da.iyai@yahoo.com \\ (Diterima: 8 Januari 2015; Disetujui: 15 April 2015)
}

\begin{abstract}
ABSTRAK
Pembangunan peternakan yang moderen membutuhkan kejelasan dan ketegasan batasan, corak dan dinamika produksinya. Penelitian eksploratif dengan metode survei melalui pendekatan Participative Rural Appraisal selama satu bulan dilakukan untuk mencatat sumberdaya yang dimiliki oleh para peternak berdasarkan kawasan agro-ekologi di Manokwari, yang meliputi Manokwari Utara, Manokwari Selatan, Warmare, Prafi, Masni, Oransbari, Ransiki, Anggi dan Minyambouw. Karakteristik agroekologi dibuat dengan software Microsoft Office VISIO. Matriks sederhana digunakan untuk pengelompokan kriteria komoditi ternak, komoditi pertanian, dan komoditi perikanan dan indikator BioFisik. Sistim peternakan terpadu yang dapat diidentifikasi pada wilayah agroekologi pesisir adalah sistim peternakan sapi berbasis tanaman kelapa (cocobeef) dan tanaman pertanian (crops livestock farming system) serta backyard poultry farming system. Pada daerah dataran rendah sistim yang dikembangkan adalah cattle-palm farming system, pig palm farming system, goat faming system, poultry farming system dan Crops livestock farming system. Pada kawasan Agroekologi Dataran Tinggi, Crop Pig Farming System, Poultry Farming System dan Backyard Cattle farming system sudah dikembangkan.
\end{abstract}

Kata kunci: sistim peternakan terintegrasi, komoditi peternakan, komoditi pertanian, agro-ekologi

\section{ABSTRACT}

A modern livestock development needs clarity, boundary, types and dynamic production within its system. An explorative survey using Participative Rural Appraisal (PRA) approach had been applied to identify the farmer resources based on Agro-ecological zone in Manokwari, West Papua. A simple matrix was created in the effort of grouping farming systems based on livestock commodities and other bio-physical components using VISIO. The survey showed that there is an integrated livestock farming systems in coastal Manokwari; i.e. coco beef, crops-livestock farming and backyard poultry farming system. In lowland area, there were cattle-palm farming systems, pig palm farming, goat farming, poultry farming and crops-livestock farming systems. In highland area, it was found a crop-pig farming, poultry farming and backyard cattle farming systems.

Keywords: Integrated livestock farming systems, livestock commodities, agro-ecology

\section{PENDAHULUAN}

Ketidakjelasan pembagian kawasan agro-ekologi pertanian di Indonesia dalam rangka spesifikasi dan diversifikasi pertanian terintegrasi disinyalir merupakan kelemahan perencanaan pembangunan pertanian di Indonesia yang menyebabkan Indonesia masih mengimport sejumlah komoditi pertanian dari manca negara. Hal ini bukan saja terjadi di Pulau Jawa yang pertaniannya sudah maju, beberapa daerah di luar pulau Jawa seperti Sumatera, dan Sulawesi serta Kalimantan pula masih mengalami situasi yang sama (Soetrisno, 2008). Lain halnya dengan Bali dan Pulau Nusa Tenggara Barat yang selalu 
masih mempertahankan corak pertanian tradisional-moderennya sampai sekarang. Hal ini tetap eksis karena sistim pertaniannya telah diketahui dan diintegrasikan dengan rencana tata ruang dan tata wilayah yang sah pada level nasional dan provinsi. Beberapa provinsi lain pada kawasan Indonesia Timur seperti Nusa Tenggara Timur, Maluku, Papua dan Papua Barat masih mengalami stagnasi disebabkan oleh ketidakjelasan pengetahuan tentang komponen sistim pertanian terintegrasi.

Di Papua dan Papua Barat, pengetahun atau informasi akan sistim pertanian terintegrasi sangat kurang. Beberapa daerah yang sedang dilakukan studi peternakan terintegrasi adalah Wamena dengan sistim sweet-potatoes pigs system (Piters, 2001), dan di Manokwari dengan sapi- dan babi- pada lahan kelapa sawit (Basna, 2011). Ternak sapi adalah komoditi unggulan yang sedang dikembangkan di Indonesia. Oleh sebabnya banyak dikembangkan sistim peternakan sapi dengan beberapa komoditi pertanian dan perkebunan seperti yang dilaporkan oleh Diwyanto dan Priyanti (2009) di beberapa daerahseperti di Jawa Tengah (Prawirodigdo, 2008), Anggraeni dan Umiyasih (2008) dan Sirappa (2003), di Jawa Timur (Anggraeny dkk., 2006).

Beberapa komoditi pertanian yang ditanam adalah padi sawahdan padi ladang, jagung, ubi kayu, ubi jalar, kacang tanah, kacang kedelai dan kacang hijau (Badan Pusat Statistik Papua Barat, 2011). Data produksi yang dipaparkan diatas masih mendominasi produksi, walaupun belum optimal, pada beberapa kabupaten dan kota di Papua Barat. Dengan adanya produksi pertanian dan perkebunan yang dilakukan di Manokwari, diprediksikan berkembang pula sistim peternakan, dimana masyarakat cenderung memanfaatkan produksi pertanian dan limbahnya (pakan nonkonvensional).

Sistim peternakan terpadu antara ternak dan tanaman pertanian di Indonesia disampaikan oleh Kusnadi (2008), dan Indraningsih dkk (2010). Sistim peternakan dengan perkebunan kelapa sawit disampaikan oleh Widjono dkk.. Di Nusa Tenggara Barat slogan Sistim Bumi Sejuta Sapi (NTB-BSS) menjadi pola yang jelas di dalam peningkatan produktifitas peternakan sapi. Di Papua Barat, slogan Bumi Sejuta Ranch (BSR) masih dalam tahap pra-konstruksi. Pemetaan dan pembangunan mini ranch sampai dengan introduksi jenis-jenis hijauan pakan ternak (HPT). Di Manokwari sistim peternakan terpadu relatif jarang dilakukan. Iyai (2008) baru mengidentifikasikan sejumlah sistim peternakan pada komoditi ternak babi sebanyak 4 sistim. Pada kawasan AgroEkologi pesisir dan kawasan dataran rendah Warmare dan Prafi. Randa (1994) telah melihat sistim peternakan babi dataran tinggi di Irian Jaya yaitu Manokwari dan Wamena.

Sistim integrasi peternakan-tanaman pertanian/integrated livestock-crops systems (ICLS) adalah model pengembangan sistim pertanian moderen yang telah dikembangkan pada negara-negara ekonomi baru seperti di China, India dan Brasil. Di Indonesia sendiri sistim peternakan terpadu (Kusnadi et al., 1993 dan Nitis et al., 1993) adalah konsep pertanian lama yang sampai saat ini masih bersifat tradisional dan dilakukan dalam skala yang kecil. Padahal teknologi pertanian skala rumah tangga ini telah banyak di adopsi oleh negara-negara maju untuk dilaksanakan di negara Amerika Latin, Asia Tenggara dan Afrika. Di Indonesia dan juga Pasifik, sistim pertanian terpadu belum dikembangkan dengan baik. Hal-hal yang menyebabkan sistim pertanian terpadu belum berjalan dengan baik adalah lemahnya regulasi pemerintah dalam penataan lokasi pertanian dan tidak adanya keseriusan dalam memajukan sistim pertanian yang telah eksis. Sistim peternakan terpadu ini belum di lihat sebagai suatu aset yang potensial dengan melihat komponen input, proses dan output yang berkeseinambungan (Kusnadi et al., 1993). Tidak dibentuknya secara jelas adanya batasan sistim pertanian di Manokwari menyebabkan produktifitas ternak per ekor menjadi rendah, produktifitas ternak per induk menjadi rendah dan produktifitas pertanian menjadi rendah. Penggunaan sumberdaya onfarm secara finansial dalam alokasi peningkatan satuan input (faktor produksi) yang 
belum bijak dan arif sehingga belum dapat memberikan keuntungan yang maksimal dari sisi on-farm income generation (Suratiyah, 2008). Hal ini menyebabkan lahan-lahan marginal di Papua dan Papua Barat menjadi ter-marginal-kan. Implikasinya adalah banyak petani dan peternak yang di resetlemen di Manokwari memilih untuk mencari off-farm income generation.

Padahal kawasan agro-ekologi yang ada di Manokwari (Iyai, 2011) memiliki potensi yangdapat memuaskan peternak dan petani. Namun sejauh ini studi-studi yang dilakukan seperti Randa (1994), belum menggambarkan sistim peternakan dataran tinggi dengan baik. Tujuan penelitian ini dapat diidentifikasikannya keragaman sistim-sistim peternakan terpadu berbasis tanaman pertanian dan perkebunan dengan jelas dan tegas di Manokwari sehingga dapat didesain modelmodel sistim peternakan terpadu.

\section{METODE}

Lokasi penelitian meliputi kawasan Agroekologi pesisir Manokwari Utara yang meliputi kampung Warbefor, Meyes, dan Saubeba, Asai, Sairo, Bremi dan Mubri. Dataran rendah Manokwari meliputi lembah Prafi yaitu di kampung Indisey, Umbuy, SP 2, SP 3, SP 4, SP 5, SP 6 dan Sumber Boga (SP 7). Sementara kawasan dataran tinggi Manokwari yaitu Distrik Minyambow pada kampung Mokwam dan Handuk. Daerahdaerah ini mewakili kawasan agro-ekologi dataran tinggi di Manokwari yaitu 1277 sampai 1488 mdpl. Selama kurang lebih empat minggu dilakukan pengambilan data dan wawancara pada kawasan ini.

Penelitian deskriptif dilakukan dengan teknik penelitian Survei (Nasir, 1988). Survei dilakukan pada kawasan Agro-Ekologi potensial di Manokwari Papua Barat, yang meliputi daerah distrik Pantai Utara, Manokwari Selatan, Warmare, Prafi, Masni, Minyambow. Partisipatory rapid apraisal (PRA) dipakai sebagai pendekatan (approach) untuk melakukan potret daerah penelitian bersama masyarakat secara holistik (Holistic approach). Pendekatan Reduksionistik (Reductionistic approach) dipakai untuk menjelaskan sebuah sistim yang secara dominan dilakukan oleh peternak terintegrasi misalnya dalam satu komoditi ternak seperti ternak sapi atau ternak babi. Sampel responden dipilih secara purposive (Maleong, 1991) sebanyak $10 \%$ dari total penduduk kampung yang riil. Identifikasi sistim peternakan terpadu adalah deskripsi tipe-tipe peternakan dan pertanian terpadu. Identifikasi dilakukan berdasarkan aplikasi tanaman pertanian dan perkebunan di Manokwari terhadap pola pemeliharaan ternak yang dimiliki oleh peternak. Karakteristik dibedakan berdasarkan kawasan agro-ekologi pesisir, dataran rendah dan dataran tinggi di Manokwari dan sekitarnya. Indikator lain yang akan dipakai adalah sumberdaya BioFisik seperti sungai, danau, kolam, hutan tanaman, dan perikanan. Sumber input $(\mathrm{Rp} / \mathrm{kg})$ adalah komponen-komponen produksi peternakan dan pertanian yang digunakan untuk meningkatan kapasitas produk peternakan dan pertanian. Proses $(\mathrm{Rp} / \mathrm{Kg})$ adalah hubungan antara komponen produksi yang saling berhubungan (interelasi) di dalam sebuah sistim. Output (Rp/kg) adalah hasil produksi dari komponen-komponen proses yang saling berhubungan (Suratiyah, 2008). Model yang dihasilkan dibuat dalam bentuk matriks sederhana. Dari matriks ini diperoleh jumlah sistim pertanian dan peternakan terpadu yang eksis di Manokwari. Selanjutnya analisis kontekstual dilakukan dalam hal komoditi peternakan dengan kawasan agroekologi yang ada di Manokwari. Mental Model dibuat dengan menggunakan software Microsoft Office VISIO 2007.

\section{HASIL DAN PEMBAHASAN}

\section{Konteks Wilayah Studi Sistim Peternakan Terpadu di Manokwari}

Dalam sub bab berikut akan dibahas kontekstual penelitian dengan mendeskripsi 


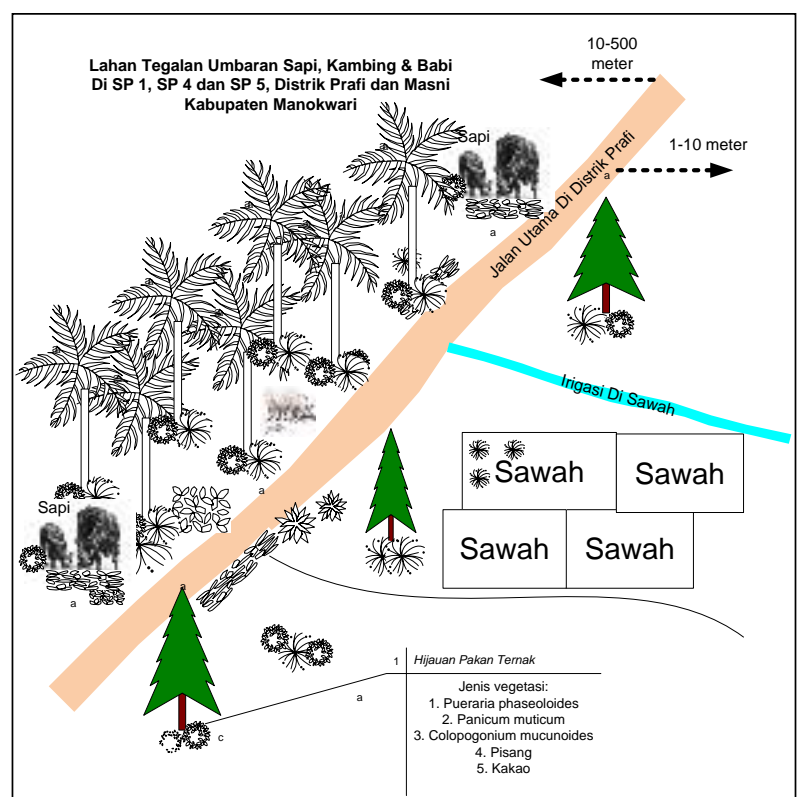

Gambar 1. Lahan tegalan umbaran babi dan sapi di Manokwari Utara

hal-hal apa saja yang sedang berlangsung pada usaha tani peternakan, bagaimana hal-hal itu terjadi atau dilakukan oleh peternak dan kapan hal-hal tersebut dilakukan oleh peternak.

\section{Profil Peternakan Pesisir}

Komoditi dan varietas ternak yang dipelihara oleh peternak pada wilayah pesisir relatif homogen dan tidak bervariasi. Jenis ternak yang dominan dipelihara adalah babi, dan ayam kampung. Ternak sapi dan kambing relatif baru dipelihara oleh peternak. Rataan kepemilikan (herd size) untuk ternak babi adalah 3 ekor, sedangkan ayam kampung 4 ekor, sapi 2 ekor dan kambing 1 ekor. Pada wilayah pesisir komoditi ternak kambing dapat dijumpai pada daerah Susweni (130 m dpl). Sementara ternak babi dapat ditemukan pada hampir setiap kampung di wilayah Pesisir Manokari Utara, dengan ketinggian lokasi 0-30 m dpl (Iyai, 2008). Ternak sapi relatif juga dibudidayakan oleh peternak di pesisir Utara. Ternak sapi yang pelihara diperoleh peternak melalui beberapa program pemerintah seperti LM3 dan BPLM serta sapi Bansos (Aronggear, 2012). Selain itu ternak sapi diusahakan masyarakat secara swadaya melalui pembelian dan bantuan dari keluarga dekat.

Peternakan Pesisir sangat bergantung pada produksi hasil pertanian dan perkebunan pesisir. Produk pertanian dan perkebunan yang dimanfaatkan peternak relatif seragam. Produk pertanian yang dimanfaatkan peternak adalah ubijalar, ubi kayu, dedaunan ubijalar, dan ubi kayu. Sedangkan produk perkebunan yang dimanfaatkan peternak adalah kelapa, dedaunan nangka, dan pisang. Tanaman pakan ternak lain diambil dari hijauan non pertanian dan perkebunan seperti rumput pakan ternak dan legum. Jenis rumput yang dimanfaatkan ternak adalah Themeda arguens, Paspalum conjugatum, Digitaria sp, Imperata cylindrica, Cyperus rotundus dan Eleusine indica. Jenis legume yang dimanfaatkan ternak adalah Micania micrantha, Ipomea batatas, Mucuna bracteata. Jenis residues yang dimanfaatkan ternak biasanya dari hasil pertanian seperti batang jagung (Zea mayes), daun kacang tanah, batang pisang (Musa indica), dan batang keladi. Produksi bahan segar, produksi bahan kering dan kapasitas tampung pada padang alami di Manokwari Utara belum dilakukan. Sumber daya alam lahan yang digunakan sebagai lahan umbaran ternak dan budidaya hijauan pakan ternak (HPT) relatif terbatas. Gambar 1 diketahui bahwa ternak umumnya diumbar pada lahanlahan kosong yang berjarak 1-10 meter dari sisi ruas jalan. Sumberdaya lain yang digunakan juga adalah air. Air digunakan sebagai air minum dan memandikan ternak dan membersih kandang ternak. Air yang digunakan berasal dari air tanah, mata air dan 


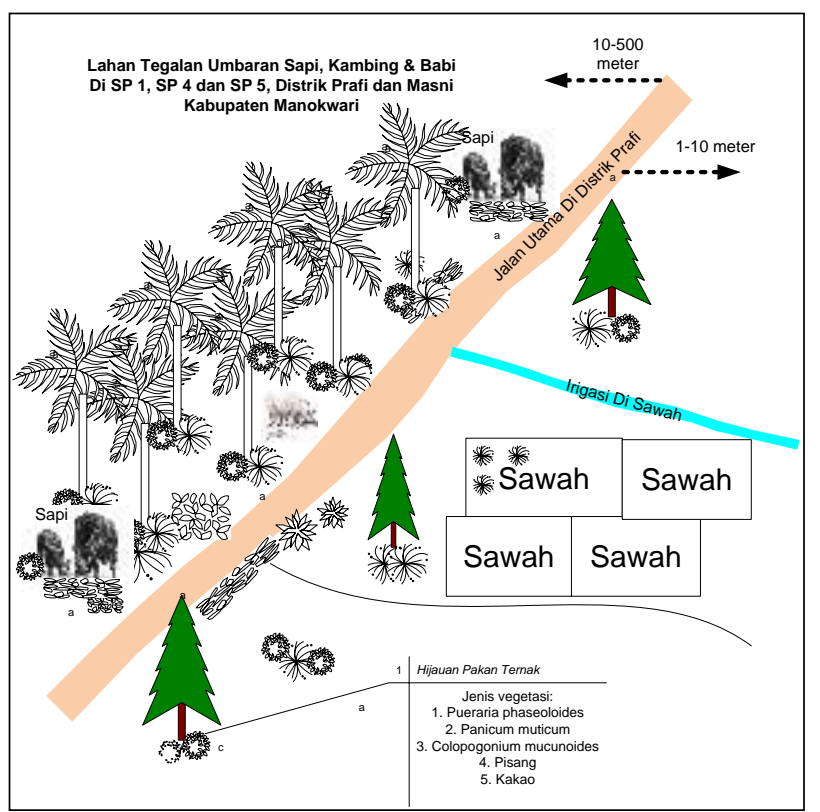

Gambar 2. Lahan tegalan umbaran di agroekologi dataran rendah Prafi.

air hujan. Mineral bagi ternak diperoleh dalam jumlah kecil berasal dari garam dapur $(\mathrm{NaCl})$. Garam dapur diberikan kepada ternak sapi dan babi untuk meningkatkan nafsu makan (palatabilitas). Sedangkan suplemen makanan tidak diberikan kepada ternak pada wilayah pesisir. Air laut sebagai sumber mineral belum dimanfaatkan sebagai campuran bahan pakan ternak untuk meningkatkan efek palatabilitas pakan. Oleh karenanya diperlukan teknologi untuk meningkatkan palatabilitas pakan ternak.

Pola/tatalaksana budidaya ternak dilakukan secara ekstensif sampai dengan sistim intensif. Misalnya Awom (2011) yang mendaptkan bahwa usaha ternak babi sudah dilakukan secara semi-komersil dan komersil. Ditemukan di beberapa kampung yang ternaknya telah dikandangkan. Babi adalah ternak yang umumnya relatif telah mendapatkan perhatian dari peternak. Kandang yang dibuat adalah sistim kandang tunggal dan panggung serta kandang tunggal yang telah dicor dengan beton seperti di wilayah Padarni, dan Anggrem (Iyai, 2008). Di daerah Manokwari Utara, jenis kandang panggung beralaskan lembaran papan masih dipakai secara dominan seperti di Warbefor, Meyes, dan Saubeba (Iyai, dkk. 2011). Di Saubeba, beberapa peternak sudah menggunakan lantai kandang cor semen. Aspek marketing belum tercipta dengan baik. Market yang terbentuk adalah pasar tidak bergerak yang diklasifikasikan oleh Rahardi dan Hartono (2002) menjadi pasar Fisik. Peternak biasanya secara musiman dikunjungi oleh pedagang pengumpul untuk mengumpulkan hasil ternak yang akan dijual oleh peternak. Ternak yang biasanya dibeli oleh pedagang pengumpul atau konsumen adalah ternak babi, sapi dan ayam kampung.

Aspek Sosial-budaya pada peternak di wilayah Pesisir Utara Manokwari relatif kuat. Hal ini terjadi ketika terdapat kepentingan sosial yang harus dilakukan, maka peternak akan berusaha melakukan kewajibannya terhadap persoalan sosial kemasyarakatan. Aspek sosial yang terjadi seperti denda, harta kawin dan parti. Dena terjadi ketika ternak yang diumbar merusak pekarangan atau halaman masyarakyat lain. Selain itu denda yang disebabkan oleh persoalan antar masyarakat. Hal ini menyebabkan ternak harus disembelih oleh peternak lain sebagai akibat dari upaya tuntutan yang dilakukan.

\section{Profil Peternakan Dataran Rendah}

Jenis ternak yang dipelihara relatif seragam dan bervariatif. Jenis ternak yang dipelihara oleh peternak di Dataran Rendah Prafi adalah babi, ayam kampung, sapi dan kambing. Jenis ternak babi yang dipelihara adalah tidak terbatas pada babi lokal, namun sudah dipelihara beberapa babi crosbreed seperti Landrach dan Saddle back. Sedangkan 
ternak sapi sudah dipelihara juga crossbred seperti Limousin dan Simental. Untuk ternak kambing, masyarakat peternak sudah dikenalkan dengan ternak kambing Peranakan Ettawah (PE). Rataan kepemilikan untuk ternak babi adalah 3 ekor, sedangkan ayam kampung 4 ekor, sapi 2 ekor dan kambing 1 ekor. Ternak sapi yang pelihara diperoleh peternak melalui beberapa program pemerintah seperti LM3 dan BPLM serta sapi Bansos.

Sumber daya alam lahan yang digunakan sebagai lahan umbaran ternak dan budidaya hijauan pakan ternak (HPT) relatif terbatas. Gambar 2 diketahui bahwa ternak umumnya diumbar pada lahan-lahan kosong yang berjarak 10-500 meter dari sisi ruas jalan. Bahkan disisi ruas kiri jalan dimana tanaman kelapa sawit mendominasi ternak sapi, babi dan kambing dapat diumbar kedalam sampai dengan jarak 500 meter. Sumber daya alam yang digunakan juga adalah air minum yang berasal dari air tanah, mata air dan air hujan. Mineral bagi ternak diperoleh dalam jumlah kecil berasal dari garam dapur $(\mathrm{NaCl})$. Garam dapur diberikan kepada ternak sapi dan babi untuk meningkatkan nafsu makan (palatabilitas). Sedangkan suplemen makanan diberikan kepada ternak pada wilayah Dataran Rendah Prafi, Masni dan Warmare.

Jenis rumput yang diberikan kepada ternak dalam bentuk digembalakan dan dipotong adalah Thema arguens, Paspalum conjugatum, Echinocloa colonum, Rhynocospora corymboza, Digitaria sp., Imperata cylindrica, Cyperus rotundus, Eleusine indica. Legum yang dimakan ternak adalah Micania micrantha, Ipomea batatas dan Mucuna bracteata. Beberapa hijauan Non Pakan ternak adalah Sphenomeris chusana, Aster ageratoides. Jenis residues yang dimanfaatkan peternak adalah seperti sisa tanaman padi, daun pisang, dan daun nangka. Aspek marketing telah tercipta dengan baik. Hasil penelitian Sumpe (2006) telah memetakan Agribisnis Peternakan sapi di lembah Prafi. Market yang terbentuk adalah pasar bergerak dan tidak bergerak. Peternak biasanya secara musiman berkunjung ke kota terdekat di SP 7 dan SP 4 untuk menjajakan hasil produk ternaknya. Pasar tidak bergerak terjadi ketika peternak sebagai konsumen dikunjungi oleh pedagang pengumpul untuk mengumpulkan hasil ternak yang akan dijual oleh peternak. Ternak yang biasanya dibeli oleh pedagang pengumpul atau konsumen adalah ternak babi, sapi dan ayam kampung. Aspek Sosial-budaya pada peternak di wilayah Dataran Rendah Manokwari relatif kuat pada peternak lokal etnis Arfak. Hal ini terjadi ketika terdapat kepentingan sosial yang harus dilakukan, maka peternak akan berusaha melakukan kewajibannya terhadap persoalan sosial kemasyarakatan. Aspek sosial yang terjadi seperti denda, harta kawin dan pesta. Denda terjadi ketika ternak yang diumbar merusak pekarangan atau halaman masyarakyat lain. Selain itu denda yang disebabkan oleh persoalan antar masyarakat. Hal ini menyebabkan ternak harus disembelih oleh peternak lain sebagai akibat dari upaya tuntutan yang dilakukan.

\section{Profil Peternakan Dataran Tinggi}

Jenis ternak yang dipelihara relatif homogeny dan tidak bervariatif. Jenis ternak yang dipelihara oleh peternak di Dataran Tiggi Minyambouw adalah babi, ayam kampung, dan sapi. Jenis ternak babi yang dipelihara adalah babi lokal, namun sudah dipelihara beberapa babi crosbreed seperti Landrach dan Saddle back. Sedangkan ternak sapi sudah dipelihara juga crossbred seperti cross Limousin dan cross Simental. Rataan kepemilikan untuk ternak babi adalah 3 ekor, sedangkan ayam kampung 4 ekor, dan sapi 1 ekor. Sementara ternak babi dapat ditemukan pada hampir setiap kampung di Distrik Minyambouw. Ternak sapi relatif jarang juga dibudidayakan oleh peternak di Dataran Tinggi. Ternak sapi yang pelihara diperoleh peternak melalui beberapa program pemerintah seperti LM3 dan BPLM serta sapi Bansos. Hasil pemantauan di lapang bahwa ternak sapi dipelihara pada lahan tegalan yang datar landai dengan luasan terbatas sampai dengan berbukit. Sumber daya alam yang digunakan juga adalah air minum yang berasal dari air tanah, sungai kecil dan air hujan. 


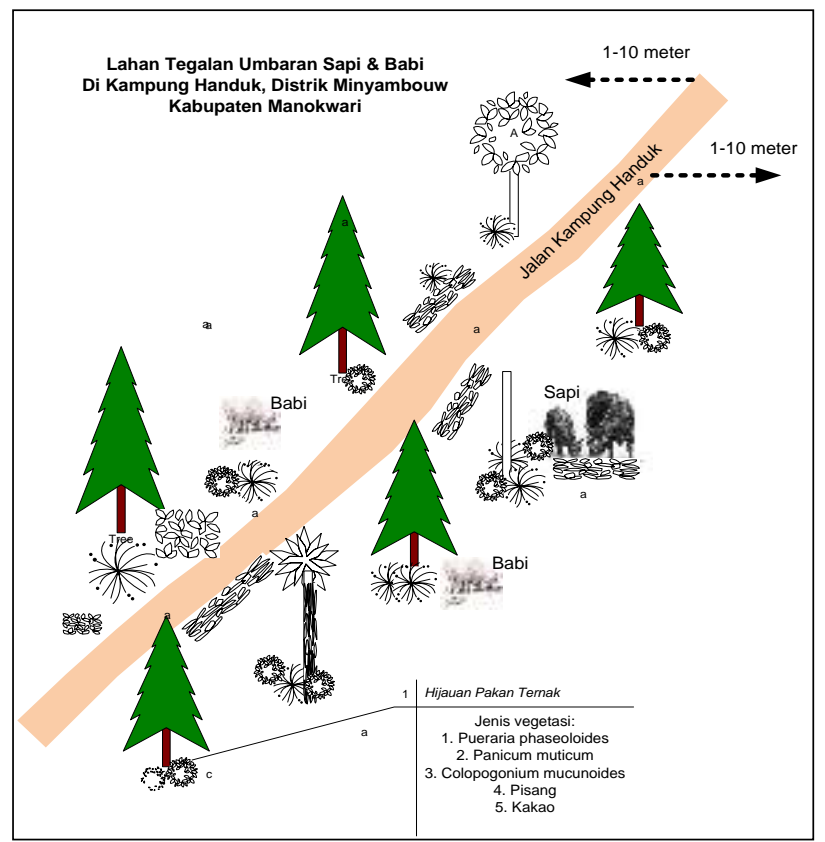

Gambar 3. Lahan tegalan umbaran ternak sapi dan babi di Kampung Handuk, Distrik Minyambouw.

Mineral bagi ternak diperoleh dalam jumlah kecil berasal dari garam dapur $(\mathrm{NaCl})$. Jenis rumput yang diberikan kepada ternak dalam bentuk digembalakan adalah Thema arguens, Paspalum conjugatum, Echinocloa colonum, Rhynocospora corymboza, Digitaria sp., Imperata cylindrica, Cyperus rotundus, Eleusine indica. Legum yang dimakan ternak adalah Micania micrantha, Ipomea batatas dan Mucuna bracteata. Beberapa hijauan Non Pakan ternak adalah Sphenomeris chusana, dan Aster ageratoides. Jenis residues yang dimanfaatkan peternak adalah seperti daun pisang, daun nangka, daun labu siam, sisa daun kol, dan sisa tanaman sayuran lainnya.

Aspek marketing belum tercipta dengan baik. Market yang terbentuk adalah pasar tidak bergerak. Peternak biasanya secara musiman berkunjung ke kota terdekat di SP 2 , pasar Warmare dan atau Manokwari untuk menjajakan hasil produk ternaknya. Pasar tidak bergerak ternyata lebih dominan. Pasar ini terjadi ketika peternak sebagai konsumen dikunjungi oleh pedagang pengumpul untuk mengumpulkan hasil ternak yang akan dijual oleh peternak. Ternak yang biasanya dibeli oleh pedagang pengumpul atau konsumen adalah ternak babi, ayam kampung dan sebagian kecil ternak sapi.
Aspek Sosial-budaya pada peternak di wilayah Dataran Tinggi Manokwari relatif kuat pada peternak lokal etnis Arfak. Hal ini terjadi ketika terdapat kepentingan sosial yang harus dilakukan, maka peternak akan berusaha melakukan kewajibannya terhadap persoalan sosial kemasyarakatan. Aspek sosial yang terjadi seperti denda, harta kawin dan parti.

Denda terjadi ketika ternak yang diumbar merusak pekarangan atau halaman masyarakyat lain. Selain itu denda yang disebabkan oleh persoalan antar masyarakat. Hal ini menyebabkan ternak harus disembelih oleh peternak lain sebagai akibat dari upaya tuntutan yang dilakukan.

\section{Deskripsi Peternakan Terpadu}

\section{Sistim peternakan pesisir}

Lokasi yang di survei adalah Distrik Pantura dan Distrik Manokwari Barat. Ditemukan beberapa sistim peternakan terpadu/terintegrasi (Integrated LivestockCrops Systems; ILCSs) (Tabel 1). Sistim peternakan terpadu (SPT) yang ada pada corak agroekologi pesisir adalah Sistim Peternakan Sapi Kelapa (cocobeef) dan Sapi Palawija (Crops cattle). Sistim peternakan babi dibawah naungan kelapa (cocopigs), palawija 
Tabel 1. Matriks klasifikasi sistim peternakan terpadu di Wilayah Pesisir Manokwari.

\begin{tabular}{|c|c|c|c|c|c|c|c|c|c|}
\hline \multirow{3}{*}{\multicolumn{2}{|c|}{$\begin{array}{l}\text { Peternakan } \\
\text { (A) }\end{array}$}} & \multicolumn{6}{|c|}{ Pertanian (B) } & \multirow{3}{*}{\multicolumn{2}{|c|}{$\begin{array}{l}\text { Perikanan } \\
\text { (C) }\end{array}$}} \\
\hline & & \multirow{2}{*}{$\begin{array}{c}\text { B1 } \\
\text { Padi }\end{array}$} & \multirow{2}{*}{$\begin{array}{c}\text { B2 } \\
\text { Kacang }\end{array}$} & \multirow{2}{*}{$\begin{array}{c}\text { B3 } \\
\text { Kelapa }\end{array}$} & \multirow{2}{*}{$\begin{array}{c}\text { B4 } \\
\text { Sawit }\end{array}$} & \multirow{2}{*}{$\begin{array}{c}\text { B5 } \\
\text { Palawija }\end{array}$} & \multirow{2}{*}{$\begin{array}{c}\text { B6 } \\
\text { Ubijalar }\end{array}$} & & \\
\hline & & & & & & & & & \\
\hline A1 & Sapi & & & A1B3 & & A1B5 & & & \\
\hline A2 & Babi & & & A2B3 & & A2B5C3 & A2B 6 C 3 & IKan Sungal & $\mathrm{Cl}$ \\
\hline A3 & Kambing & & & A3B3 & & A3B5 & A4B6 & & \\
\hline A4 & Ayam & & A4B2 & A4B3 & & A5B5 & A5B6 & Ikan Kolam & $\mathrm{C} 2$ \\
\hline A5 & Itik & & & & & & & & $\mathrm{C} 3$ \\
\hline & & & & 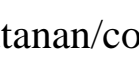 & $\sigma r$ & brio & & & \\
\hline
\end{tabular}

Tabel 2. Matriks klasifikasi sistim peternakan terpadu di Wilayah Dataran Rendah Manokwari.

\begin{tabular}{|c|c|c|c|c|c|c|c|c|c|}
\hline \multirow{3}{*}{\multicolumn{2}{|c|}{ Peternakan (A) }} & \multicolumn{6}{|c|}{ Pertanian (B) } & \multirow{3}{*}{\multicolumn{2}{|c|}{$\begin{array}{l}\text { Perikanan } \\
\text { (C) }\end{array}$}} \\
\hline & & \multirow{3}{*}{$\begin{array}{c}\text { B1 } \\
\text { Padi } \\
\text { A1B1 }\end{array}$} & \multirow{2}{*}{$\begin{array}{c}\text { B2 } \\
\text { Kacang }\end{array}$} & \multirow{2}{*}{$\begin{array}{l}\text { B3 } \\
\text { Kelapa } \\
\end{array}$} & \multirow{3}{*}{$\begin{array}{l}\text { B4 } \\
\text { Sawit } \\
\text { A1B4 }\end{array}$} & \multirow{3}{*}{$\frac{\text { B5 }}{\frac{\text { Palawija }}{\text { A1B5 }}}$} & \multirow{2}{*}{$\begin{array}{c}\text { B6 } \\
\text { Ubijalar }\end{array}$} & & \\
\hline & & & & & & & & & \\
\hline A1 & Sapi & & & & & & & & \\
\hline A2 & Babi & & & & A2B4 & A2B5 & A3B6 & IKan Sungal & Cl \\
\hline A3 & Kambing & A3B1 & & & A3B4 & A3B5 & & & \\
\hline A4 & Ayam & $\mathrm{A} 4 \mathrm{~B} 1 \mathrm{C} 2$ & & & A4B4 & A4B5C2 & & Ikan Kolam & $\mathrm{C} 2$ \\
\hline A5 & Itik & A5B1 & & & & A5B5 & A5B6 & Ikan Laut & C3 \\
\hline
\end{tabular}

Kehutanan/corak agro-ekologi (D)

dan ubijalar (Crop pig farming). Sistim peternakan kambing dibawah naungan kelapa, palawija dan ubijalar. Sistim peternakan ayam kampung dengan perpaduan kacang tanah, kelapa, palawija dan ubijalar. Sejauh ini tidak ditemukan sistim peternakan itik pada daerah pesisir. Aplikasi pakan berupa ikan laut diberikan pada sistim peternakan babi palawija dan ubi jalar. Hal ini diberikan sebagai sumber protein hewani pada ransum pakan yang diberikan.

Pada sistim peternakan terpadu (ILCSs) di kawasan agroekologi pesisir ditemui jumlah peternak sebanyak 39 orang yang meliputi sistim peternakan sapi berbasis kelapa sebanyak 3 orang $\mathrm{kk}$, sistim peternakan berbasis palawija sebanyak $5 \mathrm{kk}$. Selanjutnya ditemukan juga sistim peternakan babi berbasis tanaman kelapa (coco-pigs) sebanyak $5 \mathrm{kk}$, ternak babi berbasis palawija dan ubijalar sebanyak $5 \mathrm{kk}$. Peternakan kambing dengan sistim terpadu kelapa ditemukan $2 \mathrm{kk}$ diikuti dengan sistim kambing palawija juga sebanyak $2 \mathrm{kk}$ dan kambing ubijalar sebanyak 2 kk. Sistim peternakan unggas (ayam) ditemukan sebanyak $3 \mathrm{kk}$ diikuti dengan sistim terpadu kelapa sebanyak $2 \mathrm{kk}$, sistim ayam palawija+ubijalar juga sebanyak $5 \mathrm{kk}$.

\section{Sistim peternakan dataran rendah}

Distrik yang dikunjungi adalah Warmare, Prafi dan Masni. Ditemukan beberapa sistim peternakan terpadu/ terintegrasi (Integrated Livestock-Crops Systems; ILCSs) (Tabel 2.). Sistim peternakan terpadu (SPT) yang ada pada corak agroekologi dataran rendah adalah sistim peternakan sapi-kelapa sawit (Widjono, dkk.) dan sapi-palawija. Sistim peternakan babi kelapa Sawit, palawija dan ubijalar. Sistim peternakan kambing dibawah naungan kelapa sawit, palawija dan ubijalar. Sistim peternakan ayam kampung dengan perpaduan kacang tanah, kelapa sawit, palawija dan ubijalar. Ditemukan sistim peternakan itik pada daerah dataran rendah. Aplikasi pakan berupa ikan laut diberikan pada sistim peternakn babi palawija dan ubijalar. Hal ini diberikan sebagai sumber protein hewani pada pakan yang diberikan. 
Tabel 3. Matriks klasifikasi sistim peternakan terpadu di Wilayah Dataran Tinggi Minyambouw.

\begin{tabular}{|c|c|c|c|c|c|c|c|c|}
\hline \multirow{3}{*}{ Peternakan (A) } & \multicolumn{6}{|c|}{ Pertanian (B) } & \multirow{3}{*}{\multicolumn{2}{|c|}{$\begin{array}{l}\text { Perikanan } \\
\text { (C) }\end{array}$}} \\
\hline & \multirow{2}{*}{$\begin{array}{c}\text { B1 } \\
\text { Padi } \\
\end{array}$} & \multirow{2}{*}{$\begin{array}{c}\text { B2 } \\
\text { Kacang }\end{array}$} & \multirow{2}{*}{$\begin{array}{c}\text { B3 } \\
\text { Kelapa }\end{array}$} & \multirow{2}{*}{$\begin{array}{c}\text { B4 } \\
\text { Sawit }\end{array}$} & \multirow{2}{*}{$\begin{array}{c}\text { B5 } \\
\text { Palawija }\end{array}$} & \multirow{2}{*}{$\begin{array}{c}\text { B6 } \\
\text { Ubijalar }\end{array}$} & & \\
\hline & & & & & & & & \\
\hline Sapi & & & & & A1B5 & A1B6 & & $\mathrm{C} 1$ \\
\hline Babi & & & & & $\mathrm{A} 2 \mathrm{~B} 5$ & A2B6 & Ikan Sunga1 & \\
\hline Kambing & & & & & & & Jkan Kolam & $\mathrm{C} 2$ \\
\hline Ayam & & & & & A4B5 & A5B6 & 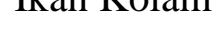 & \\
\hline Itik & & & & & & & Ikan Laut & $\mathrm{C} 3$ \\
\hline & & Keh & anan/co & $\mathrm{k}$ agro & ologi (D) & & & \\
\hline
\end{tabular}

Tabel 4. Sistim peternakan terpadu di Kabupaten Manokwari.

\begin{tabular}{|c|c|c|c|c|}
\hline \multirow[b]{2}{*}{ Komoditi } & \multirow[b]{2}{*}{ No. } & \multicolumn{3}{|c|}{ Kawasan Agroekologi } \\
\hline & & Agroekologi Pesisir & $\begin{array}{l}\text { Agrekologi Dataran } \\
\text { Rendah }\end{array}$ & $\begin{array}{c}\text { Agroekologi Dataran } \\
\text { Tinggi }\end{array}$ \\
\hline & 1 & Cocobeef & Palm-beef & Backyardbeef \\
\hline Sapi & 2 & $\begin{array}{c}\text { Crops and residual } \\
\text { Beef }\end{array}$ & $\begin{array}{c}\text { Crops and residual } \\
\text { Beef }\end{array}$ & 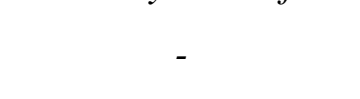 \\
\hline & 1 & Cocogoat & Palm-Goat & - \\
\hline Kambing & 2 & $\begin{array}{c}\text { Crops and Residual- } \\
\text { Goat Based }\end{array}$ & $\begin{array}{c}\text { Crops and Residual- } \\
\text { Goat Based }\end{array}$ & - \\
\hline Babi & 1 & $\begin{array}{c}\text { Kitchen and Crops- } \\
\text { Pig based } \\
-\end{array}$ & $\begin{array}{c}\text { Kitchen and Crops- } \\
\text { Pig based } \\
\text { Palm-pig }\end{array}$ & $\begin{array}{c}\text { Kitchen and Crops- } \\
\text { Pig based }\end{array}$ \\
\hline Ayam & 1 & $\begin{array}{c}\text { Backyard chicken } \\
\text { based }\end{array}$ & $\begin{array}{l}\text { Backyard housed } \\
\text { chicken based }\end{array}$ & $\begin{array}{c}\text { Backyard chicken } \\
\text { based }\end{array}$ \\
\hline Itik & 1 & - & $\begin{array}{c}\text { Kitchen and Crop- } \\
\text { Based }\end{array}$ & - \\
\hline & Jumlah & 6 & 8 & 3 \\
\hline
\end{tabular}

Pada sistim peternakan terpadu (ILCSs) di kawasan agroekologi dataran rendah ditemui jumlah peternak sebanyak 39 orang yang meliputi sistim peternakan sapi berbasis tanaman padi dan rumput pakan ternak (paddy forages based cattle farming) $4 \mathrm{kk}$, kelapa sawit sebanyak 10 orang kk, sistim peternakan sapi berbasis palawija sebanyak $5 \mathrm{kk}$. Selanjutnya ditemukan juga sistim peternakan babi berbasis tanaman kelapa sawit (palmpigs) sebanyak $5 \mathrm{kk}$, ternak babi berbasis palawija sebanyak $5 \mathrm{kk}$ dan babi berbasis ubijalar (Sweet potatoes-pig). Peternakan kambing berbasis tanaman padi sebanyak 5 $\mathrm{kk}$, dan ternak kambing berbasis kelapa sawit sebanyak $4 \mathrm{kk}$ dan palawija juga sebanyak 2 kk. Sistim peternakan unggas (ayam kampung) berbasis tanaman padi ditemukan sebanyak $3 \mathrm{kk}$ diikuti dengan sistim terpadu kelapa sawit dan kelapa sebanyak $4 \mathrm{kk}$, dan sistim ayam kampung berbasis palawija sebanyak $4 \mathrm{kk}$. Sistim peternakan itik berbasis padi ditemukan sebanyak $4 \mathrm{kk}$, dan sistim peternakan itik berbasis palawija dan ubi jalar juga sebanyak $5 \mathrm{kk}$.

\section{Sistim peternakan dataran tinggi}

Distrik yang dikunjungi adalah Minyambouw. Daerah ini memiliki ketinggian tempat $>1000 \mathrm{~m}$ dpl. Ditemukan beberapa sistim peternakan terpadu/terintegrasi (Integrated Livestock-Crops Systems; ILCSs) (Tabel 3). Sistim peternakan terpadu (SPT) yang ada pada corak agroekologi dataran tinggi adalah Sistim Peternakan babi berbasis tanaman pertanian (crops-pig farming system), chicken farming system dan Balicattle 
backyard farming system. Tanaman pertanian yang diberikan ke ternak berupa sayuran kol, petsai, buncis, buah merah, markisa, dan kentang. Selain itu tanaman rumput makanan ternak juga diberikan saat diumbar.

Karena dataran tinggi dengan ketinggian diatas $>1000 \mathrm{~m} \mathrm{dpl}$, temperatur pada Distrik Minyambouw relatif dingin. Komoditi ternak lain yang dapat dikembangkan adalah ternak kelinci. Perikanan dataran tinggi sedang dikembangkan dan masih harus dikaji potensi perikanan dataran tinggi jenis ikan apasaja yang layak dikembangkan pada daerah ini.

Ternak sapi memiliki corak sistim tersendiri dengan pakan yang digunakan oleh peternak. Kambing diusahakan hanya pada pesisir dan dataran rendah saja. Ternak babi dapat dipelihara oleh ternak sampai pada daerah dataran tinggi. Komoditi ternak ayam juga memiliki corak yang sama pada semua kawasan agroekologi. Itik hanya berkembang pada daerah dataran rendah saja (Tabel 4).

Daerah dataran rendah memiliki relative banyak variasi sistim peternakan terpadu dibandingkan dengan kedua daerah lainnya. Hal ini dimungkinkan karena daerah dataran rendah di Manokwari adalah daerah yang ditetapkan pemerintah kabupaten Manokwari sebagai daerah pengembangan pertanian dan peternakan. Daerah ini meliputi Warmare, Prafi, Masni dan Sidey.

\section{KESIMPULAN}

Sistim peternakan terpadu yang dapat diidentifikasikan pada wilayah agroekologi pesisir adalah sistim peternakan sapi berbasis tanaman kelapa (cocobeef) dan tanaman pertanian (crops and residual beef farming system), cocogoat, coco and residual-goat, kitchen and crops pig based selain itu backyard poultry chicken farming system. Pada daerah dataran rendah, sistim yang dikembangkan adalah cattle-palm farming system, pig palm farming system, goat faming system, poultry farming system dan Crops livestock farming system. Pada kawasan agroekologi dataran tinggi, sistim yang dikembangkan adalah Crop Pig Farming System, Poultry Farming System dan
Backyard Cattle farming system. Daerah agroekologi dataran rendah memiliki relatif banyak variasi sehubungan dengan daya dukung lahan dan berkembangnya daerah pertanian.

\section{DAFTAR PUSTAKA}

Anggraeni, Y. N., U. Umiyasih, D. Pamungkas dan Aryogi. 2006. Potensi bahan pakan inkonvensional asal limbah pertanian dan perkebunan di Beberapa Kabupaten di Jawa Timur. Seminar Nasional Teknologi Peternakan dan Veteriner. Hal.: 891-899.

Anggraeni, Y. N. dan U. Umiyasih. 2008. Evaluasi potensi pakan asal limbah tanaman pangan dan limbah perkebunan di Daerah Prioritas Kawin Alam Pendukung Program P2SDS. Seminar Nasional Teknologi Peternakan dan Veteriner. Hal. 304-311.

Aronggear, E.L. 2012. Evaluasi bantuan ternak sapi di kabupaten Manokwari. Skripsi. FPPK-Universitas Negeri Papua. Manokwari. Tidak diterbitkan.

Awom, M. 2010. Usahatani semi komersil dan komersil peternakan babi di Manokwari. Laporan penelitian. Fakultas Peternakan Perikanan dan Ilmu Kelautan. Universitas Negeri Papua. Tidak Dipublikasikan.

Badan Pusat Statistik Provinsi Papua Barat. 2011. Papua Barat Dalam Angka.

Basna, A. 2011. Statistik vital ternak babi yang dipelihara dibawah kelapa sawit dan yang dikandangkan. Skripsi. Fakultas Peternakan Perikanan dan Il. Kelautan. Universitas Negeri Papua. Manokwari. Tidak diterbitkan.

Diwyanto, K., B. R. Prawiradiputra dan D. Lubis. 2001. Integrasi tanaman ternak dalam pengembangan agribisnis yang berdaya saing, berkelanjutan dan berkerakyatan. Seminar Nasional Teknologi Peternakan dan Veteriner 2001. Hal.: 17-26. 
Diwyanto, K. dan A. Priyanti. 2009. Pengembangan industri berbasis sumberdaya lokal. Pengembangan Inovasi Pertanian. 2 (3) 2009: 208-228.

Iyai, D. A.. 2008. Innovation possibilities in pig keeping systems in Manokwari, Papua Barat province-Indonesia. MSc. Thesis. Wageningen University.

Iyai, D.A. dan S.Y. Randa. 2011. Characteristic of the three pig keeping systems on performances Of smallholding pig Farmers at Manokwari, West Papua. Jurnal Peternakan Indonesia. Vol 13 (2):

Iyai, D.A. M. Kayadoe, S.Y. Randa, 2011. Kajian gender dalam peternakan babi Suku Arfak di Manokwari. Laporan penelitian. FPPK-Universitas Negeri Papua. Tidak diterbitkan.

Indraningsih, R. Widyastuti, Y. Sani. 2010. Limbah pertanian dan perkebunan sebagai pakan ternak; kendala dan prospek. Lokakarya Nasional Ketersediaan IPTEKS dalam pengendalian penyakit strategis pada ternak ruminansia besar. Hal.: 99-105.

Kusnadi, U., S. Iskandar, dan M. Sabrani. 1993. Research methodology for cropsanimal systems in Hilly Areas of Indonesia. (Ed). C. Devendra dan C. Sevilla. Proceedings of an International Workshop. Crop-Animal Interaction. IRRI Discussion Paper Series No. 6. IRRI Philippines.

Kusnadi, U. 2008. Inovasi teknologi peternakan dalam sistim integrasi tanaman-ternak untuk menunjang swasembada daging sapi. Jurnal pengembangan inovasi pertanian. 1 (3): 189-205.

Moleong, L.J. 1991. Metodologi Penelitian Kualitatif. Penerbit. PT. Remaja Rosdakarya-Bandung.

Nasir, M. 1988. Metode penelitian. Penerbit Ghalia Indonesia. Jakarta.
Piters, J. 2001. Local human-sweet potato-pig systems: characterization and research in Irian Jaya, Indonesia with limited reference to Papua New Guinea. A $2^{\text {nd }}$ literature review. "Poverty Alleviation and Food Security through improving the Sweet potatoes-Pig Systems in Indonesia and Vietnam"International Potato Center (CIP).

Prawirodigdo, S. 2008. Daya dukung pakan hijauan dari limbah pertanian dan perkebunan untuk ternak kerbau rawa di beberapa daerah di Provinsi Jawa tengah. Seminar dan Lokakarya Nasional Usaha Ternak Kerbau. Hal.: 122-132.

Rahardi, F. dan Hartono, R. 2002. Seri Agribisnis: Agribisnis Peternakan. Penerbit. PT. Penebar Swadaya.

Randa S.Y. 1994. Performance of indigenous pigs of upland and lowland Irian Jaya. Thesis. Department of Animal Science. Los Baños, The Philippines.

Sirappa, M.P. 2003. Prospek pengembangan sorgum di indonesia sebagai komoditas alternatif untuk pangan, pakan dan alternatif. Jurnal Litbang Pertanian. 22 (4): 133-140.

Soekartawi. 2010. Agribisnis; Teori dan Aplikasinya. Cetakan 10. PT. Radja Grafindo Persada. Jakarta. Indonesia.

Soetrisno, L. 2008. Paradigma Baru Pembangunan Pertanian; Sebuah Tinjauan Sosiologis. Cetakan ke 3. Penerbit. Kanisius. Yogyakarta.

Sumpe, I. 2006. Kajian Tata Niaga Sapi Potong di Kabupaten Manokwari. Tesis. Universitas Gadjah Mada. Yogyakarta. Tidak diterbitkan.

Suratiyah, K. 2008. Ilmu Usahatani. PT. Penebar Swadaya. Depok. Indonesia.

Widjono, D.B., L. Affandhy dan A. Rasyid. Integrasi ternak dengan kelapa sawit. Lokakarya sistim integrasi kelapa sawitsapi. Hal.: 147-155. 